\title{
Legal and institutional consideration on FA compensation system of Korean professional football league
}

\author{
Wangsung Myung ${ }^{1}$ \& Kwangho Park ${ }^{2 *}$ \\ ${ }^{1}$ Konkok University \& ${ }^{2}$ Yonsei University
}

\begin{abstract}
[Purpose] This study examines legal and institutional aspects of FA Compensation System (FACS) which was introduced by Korean professional football league in 2013. [Methods] This legal analysis reviews the current FACS in lights of several provisions of human rights in the Constitution and other relevant rules of law. [Results] First, the FACS violates Article 15 of the Constitution that protects 'freedom of choice to workplace' arguably implied under the 'freedom of occupation' provision since the system restricts a player's transfer within the league by requiring a transfer fee paid by the destination team even if the player has acquired the free agency status and his current contract is expiring. Second, the FACS would likely be unconstitutional according to precedents decided by the Constitutional Court and the National Human Rights Commission on the ground that 'freedom of occupation' is closely related to the rights to pursue happiness under Article 10 of the Constitution. [Conclusions] Based on the legal interpretations, the study argues complete abolition or significant revision of the FACS. This project calls for follow-up studies and further policy-making efforts given the practical magnitude and scholarly merits of the issue.
\end{abstract}

Key words: FA Compensation System, Player contract, Freedom of occupation, The right to pursue happiness

\begin{abstract}
서 론
국내 프로축구리그(이하 $\mathrm{K}$ 리그)에는 선수계약과 관련 하여 독특한 '로컬 룰(local rule)'이 있다. 여기서 로컬 룰 이란 19세기 말 골프 경기에서 유래된 용어로 특정 지역 의 클럽 코스에만 적용되는 규칙을 일컫는다(“Local Rule," n.d.). 미국 법률 사전에 따르면, 연방 법규에 의 해 결정되지 않는 사항을 다루는 각 지방 법규에 관한 특 정 규정을 의미하기도 한다(“Local Rule," n.d.). 이처럼 로컬 룰은 특정 지역에만 존재하거나 적용되는 독특한 규
\end{abstract}

논문 투고일 : 2020. 03. 09

논문 수정일 : 2020. 04. 07.

게재 확정일 : 2020. 05. 10.

* 교신저자 : 박광호(pkh0977@gmail.com).
칙을 의미하며, 스포츠 종목의 경기 규칙, 국가(또는 지 역) 간 법제도적 체계, 행정 조직 등 다양한 분야에서 그 용어가 혼용되고 있다.

$\mathrm{K}$ 리그를 주관하는 한국프로축구연맹은 국제프로축구 연맹, 아시아축구연맹, 대한축구협회로 이어지는 계층 구조 속에서 복잡한 행정 체계를 이루고 있으며, 이를 바 탕으로 리그 운영과 관련된 규정을 채택하는 것이 일반적 이다.1) 따라서 리그 규정의 세부조항은 국제 및 국내 기 구와 유기적 관계를 맺고 있는 동시에 대부분 유사한 성

1) "연맹은 대한축구협회의 회원단체로서 협회, 아시아축구연맹, 국 제축구연맹의 정관, 규정, 지침 및 결정을 준수한다(한국프로축 구연맹 정관 제 1 장 제 3 조 (1)항)", "협회는 대한체육회의 회원종목 단체로서 국제적으로 한국 축구를 대표하여 국제축구연맹과 아시 아축구연맹 및 지역연맹에 가입하며, 상기단체의 정관, 규정, 지 침 및 결정을 존중한다(대한축구협회 정관 제 1 장 제 4 조 (1)항)" 
격을 지니고 있다. 그러나 이와 달리 $\mathrm{K}$ 리그에만 존재하 고 적용되는 몇 가지 예외 규정도 있다. 본 연구는 그 중 $\mathrm{FA}$ 보상금제도, 즉 '선수계약' 관련 규정에 주목하였는데, 그 이유는 해당 규정에 관한 법리적 해석과 학계의 관심 이 필요한 시점이라고 판단했기 때문이다.

Korea Professional Football League(2017, 이하 $\mathrm{KPFL}$ )의 규정집 제 2 장 제 16 조 (3)항은 "계약 종료 선수 의 이적 시 반드시 양수클럽이 원 소속 클럽에 보상금을 지급한다. 이를 위반할 경우 상벌규정에 의거 제재를 받 을 수 있다"고 규정하고 있으며, 보상금 규모는 "이적 직 전연도 기본급연액의 $100 \%$, 최대 3 억 원”으로 명시하였 다. 이처럼 $\mathrm{FA}$ 보상금제도란 $\mathrm{FA}$ 자격을 취득한 선수가 타 구단으로 이적시 이적 직전연도 소득의 $100 \%$ (최대 3억 원)을 원 소속 구단에 지급해야 하는 제도이다. 다시 말 해, 소속 구단과의 계약 기간이 끝났음에도 불구하고 $\mathrm{K}$ 리그의 다른 구단으로 이적 시 이적료 아닌 이적료가 발 생하는 것이다. 물론 $\mathrm{K}$ 리그에만 존재하는 로컬 룰이기 때문에 해외 구단으로의 이적 시에는 해당되지 않는다.

오늘날 프로스포츠시장에서 소속 구단과의 계약 기간 이 만료된 선수에게 자유계약 $(\mathrm{FA})$ 자격을 부여하는 것은 일반적인 상식이다. FA자격을 얻은 선수는 이적료라는 걸림돌 없이 자유롭게 다른 구단과 계약할 수 있는 권리 를 가질 수 있다. 선수 이적과 관련된 대표적인 판례인 1975년 미국 프로야구의 '보류 조항(Reserve clause)' 폐지와 1995년 유럽사법재판소의 '보스만 판결(Bosman ruling)'이 이를 방증한다(Hill \& Spellman, 1983; Simmons, 1997). 마찬가지로 K리그에도 자유계약 (FA)이라는 개념과 용어가 명목적으로 사용되고 있으나 자세히 들여다보면 완전한 자유가 아니다. 표면상 이적료 가 없는 자유로운 선수처럼 보일 수 있으나 $\mathrm{K}$ 리그의 $\mathrm{FA}$ 선수는 이적 시 보상금(이적료 아닌 이적료)이 발생한다. 문제는 현장(선수, 지도자, 팬)과 일부 언론의 문제의식 과 달리, 체육학계에서는 이 제도에 관한 지적 관심을 기 울이지 못하고 있다는 점이다. 최근 학계에서는 Myung(2018)이 K리그 선수들의 해외 이주 요인을 규명 하는 과정에서 $\mathrm{FA}$ 보상금제도를 직접적으로 언급한 것이 유일하다.

사실 프로스포츠선수의 계약과 관련된 연구가 학계로 부터 배제되어온 것은 아니다. 다수 연구자는 국내 프로
스포츠리그 규정 특히, 선수계약과 관련된 문제점과 개선 방안을 제시하는데 적지 않은 노력을 기울여왔다. 구체적 으로 프로야구선수 계약의 법적 성질 및 문제(Chang, 2009; Chung, 2017; Han \& Jung, 2012; Kim, 2011; Yoo, 2017a, 2017b, 2017c), 프로야구선수 계약과 대리 인제도(Lee, 2018), 프로야구선수 연봉상한제도(Ahn, 2018), 프로야구선수 FA제도(Bae, Park, Chung \& Cho, 2018), 프로야구 및 프로농구 FA선수의 보상제도 (Chang, 2011a), 프로야구 및 프로농구의 웨이버제도 (Chang, 2011b), 프로축구 드래프트제도의 법적 문제 (Kim, 2009) 등이 수행되었다. 스포츠 종목을 특정하지 않고 연구 대상을 ‘프로스포츠'로 통합한 연구들(Chang \& Kim, 2017; Kim, 2009; Yeun, 2008)도 있다.

이들 선행연구의 특징은 주로 프로야구를 중심으로 공 정거래법이나 반독점법 이론에 입각하여 선수계약과 관 련된 법제도적 연구가 수행되었다는 점이다. 유일하게 프 로축구를 대상으로 연구한 $\operatorname{Kim}(2009)$ 은 2015년에 폐지 된 드래프트 제도를 심도 있게 고찰하였다. 한편, Chang(2011a)은 종목은 다르지만 본 연구가 주목한 FA 보상금제도와 유사한 주제를 연구하였다. 그는 프로야구 및 프로농구선수의 계약만료 후 이적에 관한 법적 문제를 다루었는데, 그중에서도 '보상제도'의 법리적 해석에 초 점을 두었다. 간략히 살펴보면, 프로야구 보상제도로부 터 FA취득의 엄격한 자격요건, 과도한 보상금액, 보상선 수의 강제 이적 등 다양한 문제들이 도출되었다. 프로농 구의 경우, 구단 경기력에 큰 비중을 차지하고 있는 선수 에게만 보상제도가 적용된다는 점에서 프로야구와 차이 가 있지만 보상 방식이 보유선수의 이적이라는 동일한 문 제를 지니고 있다(Chang, 2011a). 그의 연구는 K리그 $\mathrm{FA}$ 보상금제도와의 비교 논의를 제공한다는 점에서 본 연구에도 의미가 있다.

이처럼 $\mathrm{K}$ 리그 $\mathrm{FA}$ 보상금제도는 다양한 측면에서 그 문 제들이 논의되어야 함에도 불구하고 학계로부터 관심을 받지 못한 것은 사실이다. 특히, 최근 이 제도와 관련된 실제 사례들이 여러 언론 매체를 통해 문제 제기되고 있 다는 점(Kim, 2019, Jul. 10; Kim, 2019, Aug. 1; Kim, 2017, Aug. 4; Lee, 2019, Jul. 9)에서 비판적 관 점이 견지될 필요가 있다. 이에 본 연구는 헌법 조문 및 관련 법률을 분석 틀로 차용하여 FA보상금제도에 관한 
법제도적 고찰을 수행하고자 한다.

대한민국헌법은 권력기관의 설치와 운영을 규정하고, 국내법과 제도의 최상위 근본 규범이다(Cha, Yoon \& Yoon, 2016). 따라서 '상위법 우선의 원칙'에 따라 법률 에 의거한 판단은 (상위법과 하위법이 충돌할 경우) 상위 법을 우선 적용하고, 하위법은 그 효력을 상실하게 된다 (Kim, 2016). 마찬가지로 FA보상금제도의 법리상 적용 여부는 물론 법리적 해석에 있어 관련 법률과 그 상위법 인 헌법 조항은 중요한 분석 틀을 제공한다. 그도 그럴 것 이 한국프로야구연맹의 법적 지위는 공정거래법상 사업 자단체성이 인정된 선례가 있으며(공정거래위원회 2008. 09. 17. 2008서총0765), 이는 본 연구에서 주목 한 한국프로축구연맹과 $\mathrm{FA}$ 보상금제도에 관한 법제도적 고찰의 전제라고 할 수 있다.

따라서 다음 장에서는 $\mathrm{FA}$ 보상금제도 관련 주요 용어 를 조작적으로 정의하고, 제도의 도입 배경, 목적 그리고 그 효력에 관한 이해를 선행한다. 이어서 세 번째 장은 프 로스포츠선수의 근로자성에 대한 법적 개념을 살펴봄으 로써 FA보상금제도에 관한 법리적 해석의 타당성을 확 보한다. 네 번째 장에서는 $\mathrm{FA}$ 보상금제도에 관한 법제도 적 고찰을 제공한다. 이를 위해 직업 자유와 행복추구권 에 관한 헌법 조문 및 관련 현행 법률, 헌법재판소 및 대 법원 판례, 국가인권위원회 결정례, 프로스포츠선수 계 약 관련 문헌 등을 근거 자료로 채택하여 비교 분석한다. 보조 자료로는 해외 프로스포츠리그 정관 및 규정, 프로 스포츠선수 계약 관련 유럽사법재판소 판례 등 국제 규정 과 해외 사례를 활용한다. 마지막 장에서는 법리적 해석 을 바탕으로 학술적 및 실천적 의의를 제공한다.

서론을 다시 정리하면, 본 연구는 $\mathrm{K}$ 리그의 선수계약과 관련된 로컬 룰, 즉 $\mathrm{FA}$ 보상금제도에 관한 법제도적 고찰 을 제공하는데 그 목적이 있다. 이를 통해 국내 프로축구 리그의 선수계약 규정을 어떠한 헌법적 법리와 내용에 적 용할 수 있는지 살펴보고, 향후 제기될 수 있는 문제와 그 개선방향을 모색할 수 있을 것이다. 더 나아가 국내 프로 스포츠리그 규정이 선수와 구단 간 균형 있는 중재 역할 을 수행할 수 있도록 체육학계 특히, 스포츠인문사회학 연구자들의 비판적 사고와 지속적 관심으로 이어지길 기 대해본다.

\section{FA보상금제도에 관한 이해}

본 장에서는 $\mathrm{FA}$ 보상금제도에 관한 법제도적 고찰에 앞서 해당 제도의 도입 배경, 목적 및 운영규정, 관련 용 어 등을 살펴보고자 한다. 이는 FA보상금제도가 도입된 배경 및 목적을 사회문화적 맥락을 통해 이해하고 실제 적용 사례를 검토함으로써 현장에서 이 제도가 지니는 효 력을 파악하기 위함이다. 또한, FA보상금제도와 관련된 주요 용어를 조작적으로 정의함으로써 개념적인 혼동을 예방한다.

\section{자유계약선수(FA)와 이적료}

먼저 FA보상금제도를 이해하기 위해서 주요 용어에 대한 개념적 정리가 필요하다. 그 중 본 연구에서 빈번하 게 등장하는 자유계약선수(이하 FA)와 이적료에 대한 이 해를 선행해야 한다. FA와 이적료는 $\mathrm{K}$ 리그뿐만 아니라 다른 프로스포츠리그에서도 통용하는 개념으로 선수계 약에 큰 영향을 미치고 있다. 먼저 Free Agency란 사전 적으로 "아무데도 메이지 않은 자유로운 사람(a person who can do whatever they want because they are not responsible to or for anyone else)"을 의미한다 (“Free Agency," n.d.). 이를 스포츠선수에 적용해보면, 어느 구단에도 메이지 않은 자유로운 선수 또는 선수계약 으로, 해당 선수는 원하는 구단으로 자유롭게 이적할 수 있음을 뜻한다.

$\mathrm{FA}$ 의 제도적인 의미는 프로스포츠단체에 따라 차이가 있지만 앞서 살펴본 사전적 의미를 크게 벗어나지 않고 있다. 먼저 Korea Baseball Organization(2018, 이하 $\mathrm{KBO}$ )의 ' $2018 \mathrm{KBO}$ 규약' 제 17 장 제 161 조에 따르면, $\mathrm{FA}$ 란 "(FA자격)요건을 갖추어 모든 구단과 선수계약을 체결할 수 있는 권리를 취득한 선수”이다. 여기서 FA자격 요건은 $\mathrm{KBO}$ 최초 등록 후 시범경기와 포스트시즌을 제 외한 정규시즌에서 9차례 활동한 선수이다. 2006년 이후 등록선수 기준, 당해 정규시즌 등록일수가 145 일 이상인 경우 1 시즌으로 인정한다. 단, 4 년제 대학을 졸업한 선수 의 경우 정규시즌 활동 횟수를 8차례로 규정하고 있다.

그동안 학계에서는 $\mathrm{KBO}$ 의 $\mathrm{FA}$ 선수 계약에 관한 다양 한 법리적 해석이 이루어져왔다. 특히, 「독점규제 및 공 
정거래에 관한 법률(이하 공정거래법)」의 관점에서 선수 계약서의 이용강제, 가격설정 과정, $\mathrm{FA}$ 의 엄격한 자격조 건, 계약 절차 및 방법의 불공정 행위 등 그 위법성에 주 목했다. Ahn(2018)은 FA선수 계약의 내용(특히, 가격) 에 대한 개입은 「공정거래법」제26조 (1)항을 위반할 수 있으며, 이사회에서 $\mathrm{FA}$ 선수의 거래조건과 상한 가격을 미리 정하여 합의한 경우에는 동법 제 19 조가 금지하는 카르텔에도 해당된다고 지적하였다. 그리고 이러한 $\mathrm{KBO}$ 의 규정은 어느 구단과도 자유롭게 계약할 권리가 있는 $\mathrm{FA}$ 선수의 본질적 권리를 침해한다고 주장하였다. $\mathrm{Seo}(2016)$ 역시 $\mathrm{KBO}$ 를 공정거래법의 적용을 받는 영역 으로 전제하면서 $\mathrm{FA}$ 제도에 대한 법리적 해석을 제공하 였다. 본 연구에서 주목할 부분은 $\mathrm{FA}$ 선수의 계약 절차 및 방법의 위법성으로 첫째, FA선수의 보상금 수준이 과도 하다는 점, 둘째, 지명 보상선수의 이동(이적)의 자유를 제한한다는 점, 셋째, 구단별 $\mathrm{FA}$ 선수 취득을 양적으로 제한하고 있다는 점이다 $(\mathrm{Seo}, 2016)$. 이처럼 $\mathrm{KBO}$ 의 $\mathrm{FA}$ 선수 계약은 공정거래법의 측면에서 다양한 문제점이 도출되었으며, 이는 $\mathrm{K}$ 리그 $\mathrm{FA}$ 보상금제도에 주목한 본 연구에도 유의미한 시사점을 제공한다.

본 연구 대상인 K리그의 경우, "2004년 이전에 최초 등록 후 계약기간 동안 소속 클럽이 치른 연맹 주최 공식 경기의 $50 \%$ 이상에 출전한 선수는 계약기간 만료와 동시 에 FA선수 자격을 취득할 수 있다(규정집 제 2 장 제 16 조 (1)항)." 만약 위 조항을 충족하지 못한 선수는 원 소속 클 럽이 재계약 우선권을 가지게 되고, 원 소속 클럽이 재계 약을 포기할 경우에만 FA자격을 취득할 수 있다. 문제는 2005년 이후에 등록한 선수인데, 해당 선수는 동규정 제 2 장 제 16 조 (3)항에 따라 '보상금제도'에 적용되어 경기 출전 기준을 충족하거나 원 소속 클럽과의 계약이 만료되 어도 사실상 $\mathrm{FA}$ 자격을 취득할 수 없는 상황이다. 본 연구 에서 주목한 부분이 바로 이 조항이기도 하다.

국내와 달리, 해외 프로스포츠단체에서는 $\mathrm{FA}$ 선수에 대한 정의와 취득 조건이 상대적으로 간결하다. 미국 프 로야구는 "리그에서 6 년 간 활동한 선수 또는 구단으로부 터 방출된 선수는 FA자격을 취득하게 되며, 해당 선수는 모든 구단과 자유롭게 계약할 수 있다(“Free Agency," n.d.)"고 명시하였다. 잉글랜드축구협회인 The Football Association(2019)이 규정한 'Rules of the association'
에 따르면, 계약이 종료된 선수는 FA가 되며, 이전 클럽 에 이적료를 지불하지 않고 다른 클럽과 계약할 수 있다. 이러한 사실은 국내 프로스포츠리그가 해외 리그와 비교 했을 때, FA자격 취득 요건이 엄격하다는 점을 보여준다 (Chang, 2011a).

이를 종합해보면, FA란 구단이나 연맹으로부터 어떠 한 제한을 받지 않고 원하는 구단과 자유롭게 계약할 수 있는 선수를 의미한다. 그리고 FA자격을 취득하기 위해 서는 소속 구단과의 계약이 만료되거나 해당 리그에서 정 한 기준(리그등록기간, 경기출전횟수 등)을 충족해야 한 다. 반면에 FA자격을 취득하지 못한 선수는 소속 구단의 동의 없이 다른 구단과 계약을 체결할 수 없으며, 소속 구 단은 비FA선수의 통제권을 행사할 수 있다. 따라서 비 $\mathrm{FA}$ 선수의 영입을 희망하는 구단이 있거나 비FA선수가 다른 구단으로의 이적을 희망할 경우 소속 구단은 일정 금액을 요구할 수 있다. 이때 발생하는 금액이 바로 '이적 료(transfer fee)'이다.

이적료는 FA자격 여부에 따라 발생하며, 비FA선수의 입장에서 이적을 제한하는 가장 큰 걸림돌이다. 반면에 이적료는 구단의 수익 모델 중 하나로 기능한다. 특히, 리 그 경쟁력이 낮고 재정 능력이 부족한 구단에게 이적료 수익은 상당히 중요한 부분이다. 대표적으로 네덜란드 프 로축구리그와 같은 유럽의 중·소규모 축구리그는 이적료 가 구단 수익의 큰 부분을 차지하고 있다. 최근에는 $\mathrm{K}$ 리 그 구단들 역시 소속 선수를 중국, 일본, 중동 리그로 이 적시킨 후 전례 없는 이적료 수익을 올리고 있다(Myung $\&$ Won, 2019). 이처럼 이적료는 비FA선수와 구단의 관 점에 따라 전혀 다른 의미를 지니고 있다. 본 연구에서 주 목할 부분은 K리그는 비FA선수뿐만 아니라 FA자격을 취득한 선수에게도 이적료 아닌 이적료가 발생하고 있다 는 점이다. 그리고 그 중심에는 'FA보상금제도'가 있다.

\section{$\mathrm{FA}$ 보상금제도의 도입 배경과 목적}

$\mathrm{FA}$ 보상금제도에 관한 올바른 이해를 위해서 $\mathrm{K}$ 리그의 구조적 특성과 해당 제도가 도입되기 전 $\mathrm{K}$ 리그 상황을 살 펴볼 필요가 있다. 1983년 출범한 K리그는 프로야구리 그와 마찬가지로 정부와 기업의 주도 아래 출발한 독특한 구조를 지니고 있다. 특히, $\mathrm{K}$ 리그는 기업뿐만 아니라 시 
도민구단과 같은 지방자치단체에서 운영하는 구단(성남, 대구, 경남, 강원, 대전, 광주, 인천, 수원 $\mathrm{FC}$, 안산, 안양, 부천 등)이 리그의 상당 부분을 차지하고 있다(Ministry of Culture, Sports and Tourism, 2019). 이러한 구조 는 K리그 구단들이 자생적 운영보다는 모든 수입(예산) 을 모기업과 지자체로부터 내려 받는 운영 형태로 이어졌 다(Kim, 2013; Kim \& Park, 2014; Myung, 2018). 실제로 한국프로축구연맹이 공개한 자료에 따르면, $\mathrm{K}$ 리 그 구단들의 수입 항목 중 약 $65 \%$ 를 스폰서십이 차지하 고 있는 반면, 입장료 수익은 $4 \%$ 에 불과한 것으로 나타 났다(Ahn \& Cho, 2018, Nov. 7). 여기서 스폰서십이란 구단의 모기업 또는 지자체를 의미한다. 이는 중계권 수 입이 $44 \%$, 지역 기반 및 글로벌 기업의 스폰서 수입이 $40 \%$, 입장권 관련 수입이 $16 \%$ 를 차지하는 유럽축구리 그와는 상반된 모습이다(Deloitte Sports Business Group, 2020).

이처럼 $\mathrm{K}$ 리그의 독특한 출범 배경과 운영 구조는 각 구단의 만성적인 적자 운영으로 이어졌는데, $\mathrm{K}$ 리그는 이 에 대한 원인과 해결책으로 '선수 인건비' 지출에 주목하 였다(Kim, 2012, Jan. 6; Park, 2013, Apr. 11). 여기 서 선수 인건비란 선수 연봉뿐만 아니라 특정 선수를 영 입하는 과정에서 발생하는 이적료와 각종 수당을 포함한 다. 2) 그도 그럴 것이 $\mathrm{K}$ 리그 구단의 지출 내역 중 선수 인 건비가 차지하는 비율이 $60 \%$, 선수단 운영비가 $20 \%$ 등 약 $80 \%$ 가 선수 관리와 관련이 있다(Ahn \& Cho, 2018, $\operatorname{Nov} 7$ ). 구단 수익의 상당 부분을 모기업과 지방자치단 체에 의존하는 $\mathrm{K}$ 리그에게 지나친 선수 인건비 비중은 큰 부담으로 작용한 것이다. 이러한 맥락에서 $\mathrm{K}$ 리그와 각 구단들은 선수 관리 비용, 즉 선수 인건비에 대한 개선 방 안을 지속적으로 모색하였다.

마침내 2013년, 한국프로축구연맹은 FA보상금제도 를 새로운 규정으로 도입하였다. 이 제도에 관한 세부 내 용은 〈Table 1)과 같다. 이 제도는 선수 인건비 지출 측면 에서 두 가지 기대효과를 지니고 있다. 첫째, $\mathrm{K}$ 리그 구단 들의 무분별한 이적료 지출을 제한하는 것이다. 이 당시 $\mathrm{K}$ 리그에는 여러 형태의 선수계약이 존재했으며, 크게 계

2) $\mathrm{KPFL}(2019)$ 이 공개한 $\mathrm{K}$ 리그 구단별 연봉 현황에 따르면, 계약서에 기재된 기본급뿐만 아니라 출전, 승리, 무승부, 기 타 수당 등이 연봉 산출 기준에 포함된다.
약금의 유무로 구분할 수 있다. 계약금이 있는 드래프트 계약 선수(2001년 이전)와 자유계약 선수(2002 2005 년), 그리고 계약금이 없는 드래프트 계약 선수(2006년 이후)가 그 예이다. 문제는 당시 계약금이 있는 선수의 이 적료가 구단 입장에서 상당히 부담스러운 수준이었다는 점이다. 실제로 $\mathrm{FA}$ 자격을 얻은 선수 기준으로 이적료를 산출해보면, ‘(현재 연봉+원 소속 구단이 제시한 차기 연봉+이적 구단이 제시한 연봉) $\div 3] \times$ 연령별 계수'라는 방식이 적용되었다. 예컨대, 연봉 5 억 원을 받는 30세 선 수(연령별 계수 $=3$ )가 현 소속팀에서 연봉을 동결하고, 타 팀에서는 연봉 5억 원을 제안한다면, 이때 발생하는 이적료는 15 억 원이다. 그러나 $\mathrm{FA}$ 보상금제도는 모든 $\mathrm{FA}$ 선수의 보상금 한도를 최대 3 억 원으로 제한하고, 이 를 통해 구단 간 무분별한 이적료 지출을 제한할 수 있다.

둘째, 재정이 열악한 구단에게 일정 수준의 보상금을 보장하기 위함이다. 앞서 살펴본 첫 번째 기대효과는 계 약금이 있는 선수에만 해당되는 것으로 현재 K리그에는 존재하지 않는 계약 형태이다. 따라서 계약금이 없는 형 태의 선수는 FA자격을 얻으면 이적료 없이 자유롭게 다 른 구단과 계약을 진행할 수 있다. 그러나 FA보상금제도 는 계약금 유무와 무관하게 FA자격을 얻은 선수라 할지 라도 이적을 원하는 모든 선수에게 이적료 성격의 보상금 을 지불해야 한다고 규정하고 있다. 예를 들면, $\mathrm{A}$ 구단은 계약이 만료된 소속 선수가 다른 팀으로 이적 시 이적 구 단으로부터 해당 연도의 기본급 $100 \%$ 를 받게 된다. 단, 하위 리그로의 이적 시에는 보상금이 발생하지 않기 때문 에 상대적으로 재정이 열악한 구단에게 유리한 규정이라 고 할 수 있다.

다시 정리하면, 1983 년 출범한 K리그는 독특한 구조 아래 만성적인 적자 운영을 피할 수 없는 상황이었다. 이 에 대한 원인으로 '선수 인건비' 지출에 주목하였으며, 2013년 FA보상금제도가 그 해결방안으로 도입된 것이 다. 이 제도를 통해 그동안 구단 간 거래되었던 이적료 수 준을 크게 낮추고, 궁극적으로 $\mathrm{K}$ 리그 구단들의 재정적 부담을 줄이는데 주안점을 두었다. 또한, 상대적으로 재 정이 열악한 구단에게는 $\mathrm{FA}$ 자격을 취득한 소속 선수가 타 팀으로 이적 시 일정 수준의 보상금을 지급받을 수 있 도록 규정함으로써 계약 만료와 관계없이 소속 선수에 대 한 보유 권한을 강화하였다. 
Table 1. FA Compensation System

\begin{tabular}{cl}
\hline \hline Item & \multicolumn{1}{c}{ Article 16 of Chapter 2 (FA player qualification) } \\
\hline $\begin{array}{c}\text { Clause } \\
\text { (3) }\end{array}$ & $\begin{array}{l}\text { Players under the age of } 33 \text { who have joined since } \\
\text { 2005 will be covered by the compensation system. It } \\
\text { depends on each of the following. }\end{array}$ \\
\hline 1 & $\begin{array}{l}\text { If a player whose contract is terminated transfers to } \\
\text { another club, the transfer club must pay compensation } \\
\text { to the original club. Violation of this may result in } \\
\text { sanctions under the penalty law. }\end{array}$ \\
\hline 2 & $\begin{array}{l}\text { The amount of compensation is } 100 \% \text { of the basic } \\
\text { salary of the previous year, up to 300 million won. }\end{array}$ \\
\hline 3 & $\begin{array}{l}\text { Compensation is applied to a player who registered for } \\
\text { two consecutive seasons (excluding lease) in the } \\
\text { original club. However, military service periods } \\
\text { (including social service periods) and school-going } \\
\text { players shall be applied as contract break periods in } \\
\text { accordance with Clause (1), Article 2 of Chapter 2. }\end{array}$ \\
\hline $\begin{array}{l}\text { Compensation is applied to transfers within the same } \\
\text { division or from lower divisions to higher divisions } \\
\text { and not to transfers from higher divisions to lower } \\
\text { divisions. }\end{array}$ \\
\hline $\begin{array}{l}\text { The division application of the original and transfer } \\
\text { club is as follows. } \\
\text { - The original club: Division based on the contract's } \\
\text { expiration date } \\
\text { - The transfer club: Division based on player's transfer } \\
\text { date }\end{array}$ \\
$\begin{array}{l}\text { If a player joins domestic or foreign club in order to } \\
\text { avoid compensation and transfers to another club in } \\
\text { Korea within two years (excluding military service } \\
\text { period), the original club may claim the compensation. } \\
\text { However, compensation cannot be claimed after two } \\
\text { years. }\end{array}$ \\
\hline \hline Source: KPFL(2017)
\end{tabular}

Source: KPFL(2017)

\section{$\mathrm{FA}$ 보상금제도의 사례와 그 효력}

$\mathrm{FA}$ 보상금제도가 도입된 이후 해마다 적용대상 선수가 눈에 띄게 증가하고 있다. 첫 해인 2013년에는 FA자격

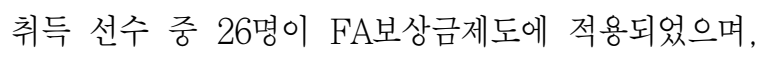
2015년 60명, 2016년 79명으로 지속적인 증가 추이를 보였다(Ahn, 2012, Dec. 18; Kim, 2014, Dec. 22; Mo, 2015, Dec. 22). 가장 최근인 2020년에는 85명이 타 구단으로 이적 시 보상금이 발생하는 것으로 나타났다 (Lee, 2019, Dec. 23). 이러한 경향은 '2005년 이후 등 록 선수'의 증가와 2015년 K리그 드래프트제도 폐지에 따른 '단기간 계약 선수'의 증가로부터 영향을 받은 것으 로 파악된다.
그렇다면 FA보상금제도는 적용 대상 선수들에게 실제 로 어떠한 효력을 지니고 있을까. K리그 선수들의 동남 아시아 국가로의 이주 요인을 분석한 Myung(2018)의 연구는 FA보상금제도의 효력과 그 결과를 잘 보여준다. Myung(2018)은 소속 구단과의 재계약에 실패한 20대 중후반 또는 30 대 선수들이 타 구단 이적을 추진하는 과 정에서 $\mathrm{FA}$ 보상금제도로 인해 큰 어려움을 겪고 있다고 보고하였다. 재정적으로 열악한 국내 구단들이 $\mathrm{K}$ 리그 평 균 연봉을 웃도는 중견 선수들을 원 소속 구단에 보상금 (해당 선수의 연봉 $100 \%$ )을 지급하고 영입하기 보다는 신인 선수나 임대 계약을 선호하기 때문이다. 결국 FA아 닌 FA선수들은 FA보상금제도라는 로컬 룰을 피해 동남 아시아 축구리그로 눈을 돌리고 있으며, Myung(2018) 은 이 현상을 비자발적 이주로 규정하였다.

이에 대해 한 언론에서는 FA보상금제도가 주류 선수 보다는 비주류 선수에게 악법으로 작용하고 있다고 강한 어조로 비판하였다(Heo, 2013, Dec. 23). 다른 언론 역 시 기량이 뛰어난 선수는 해당 규정에 별다른 영향을 받 지 않는 반면, 경기력이 하락세에 있거나 재기를 꿈꾸는 선수들에게는 문제가 된다고 하였다(Kim, 2017, Aug. 4). 다음은 FA보상금제도에 관한 사례를 다룬 언론 보도 내용이다.

"A선수는 $B$ 구단에서 3 년간의 계약기간을 채우며 FA선수 가 됐다. $B$ 구단은 $A$ 선수를 더 이상 원하지 않았다. 다행히 $\mathrm{C}$ 구단에서 새 시즌 개막이 1 달여 앞으로 다가온 시점에 $\mathrm{A}$ 선 수에게 연락을 했다. 보상금 6000 만원(직전연도 기본금연 액)을 지불하겠다며 계약 의사를 밝혔다. A선수는 급하게 C 구단에 합류해 2주 넘게 훈련을 했다. 그런데 그 사이 C구단 이 갑자기 말을 바궜다. $\mathrm{A}$ 선수에게 '보상금을 $\mathrm{B}$ 구단에게 줄 수 없게 됐다. 직접 $\mathrm{B}$ 구단에 가서 보상금 문제를 해결하고 와라. 그렇지 않으면 계약은 없던 일로 하겠다고 했다. 새 시즌이 시작되기 직전이라 다른 팀을 알아볼 수 없었다. $A$ 선 수는 $B$ 구단으로 향했다. $B$ 구단은 $A$ 선수의 사정을 듣고 보 상금을 절반만 받기로 했다. $A$ 선수는 급한 대로 가족에게 3000 만원을 빌려 보상금을 직접 해결하고 C구단에 합류했 다. $A$ 선수가 $C$ 구단으로부터 받은 연봉은 3000 만원대. $A$ 선 수는 사실상 $\mathrm{C}$ 구단에 자신의 1 년치 급여를 내고 들어가 무 료로 뛴 셈이다. (중략) 익명을 요구한 한 에이전트는 '구 단은 규정상 받을 수 있는 돈이기 때문에 굳이 포기하려 하 지 않는다. 그런데 그 구단도 FA로 풀린 선수를 데려올 땐 보상금을 내야한다는 걸 생각하면 서로가 서로의 발목을 잡 는 셈' 이라고 했다." - Kim(2017, Aug 4) 
이처럼 $\mathrm{FA}$ 보상금제도는 $\mathrm{K}$ 리그 구단 간 이적에 상당한 제약으로 기능하고 있으며, 국내 이적 시장의 침체와 일 부 선수들의 해외 유출을 야기하고 있다. 특히, 소득 수준 이 낮거나 팀 내 입지가 좁은 선수들이 그 대상이다. 실제 로 K리그 선수들의 해외 이주 동향을 살펴보면, FA보상 금제도가 도입된 2013년부터 동남아시아 국가로의 이주 가 급격히 증가하기 시작했다(Myung \& Lee, 2018). 본 연구는 이러한 문제의식으로부터 $\mathrm{K}$ 리그 $\mathrm{FA}$ 보상금제도 에 관한 법제도적 고찰을 제공하고, 이를 통해 학술적 및 실천적 의의를 도출하고자 한다.

\section{프로축구선수의 근로자성에 관한 법적 개념}

$\mathrm{K}$ 리그 $\mathrm{FA}$ 보상금제도에 관한 법제도적 고찰에 앞서 프 로축구선수의 근로자성에 대한 법적 개념을 살펴보아야 한다. 프로축구선수의 노동법상 지위가 인정되어야만 $\mathrm{FA}$ 보상금제도에 관한 법리적 해석이 그 타당성을 확보 할 수 있기 때문이다. 이를 위해 먼저 근로기준법상 근로 자와 사용자에 대한 의미를 살펴볼 필요가 있다. 「근로기 준법」제 1 장 제 2 조에 따르면, 근로자란 "직업의 종류와 관계없이 임금을 목적으로 사업이나 사업장에 근로를 제 공하는 자"이며, 사용자는 “사업주 또는 사업 경영 담당 자, 그 밖에 근로자에 관한 사항에 대하여 사업주를 위하 여 행위하는 자"이다. 다시 말해, 근로기준법에 의해 보호 되는 근로자는 사업주에 고용되어 근로를 제공하는 사람 으로 '노동의 종속성'이 핵심적인 요소이다(Im, 2019). $\operatorname{Kim}(2018)$ 역시 '노동의 종속성'을 근로기준법상 근로자 개념의 핵심 요소로 들고 있다.

이에 대해 Kwon(2012)은 스포츠 활동의 개념 요소 중 '자기목적성'과 '조직성 및 규범성'은 종속적인 노동력 지배로 볼 수 없지만 '직업활동성'의 관점에서는 다른 해 석을 내놓았다. 그는 '자기목적성'과 '조직성 및 규범성'의 성격이 강한 아마추어 선수와 달리, 프로스포츠선수는 '생계 유지목적성'과 '사실적 종속성'에 기초하기 때문에 근로자로 보아야 한다고 주장하였다. 이는 스포츠 활동이 노동법상 지위를 확보하기 위해서는 단순히 건강증진 및 경쟁의 성격에만 그치지 않고 근로(여기서는 훈련 및 경 기출전)에 대한 금전적 보상과 업무 평가적 성격을 가져
야 함을 의미한다. 이러한 관점에서 프로스포츠선수의 훈 련 참여, 경기 출전 및 진행 과정, 노무 제공의 장소 및 시 간 등이 전적으로 사용자인 구단에 의해 이루어지기 때문 에 '노동의 종속성'을 인정하는데 별다른 문제가 없다 (Kim, 2009).

한편, Yoo(2017c)는 '특수형태근로종사자'라는 개념 을 차용하여 프로야구선수를 근로기준법상 근로자로 간 주하였다. 특수형태근로종사자란 자영사업자의 성격을 가지고 있으나 특정 사업주에게만 종속 관계를 맺고 있다 는 점에서 근로기준법상 근로자와 유사한 '경제적 종속성' 을 보이는 것이 특징이다(Kim, 2016). Kwon(2018) 역 시 프로스포츠선수를 근로자로 인정하기 위한 법령개선 방안으로 특수형태근로종사자 개념을 활용하였다. 그는 프로스포츠선수는 근로자와 사용자의 특성을 동시에 지 니고 있으며, 노무의 제공이 특수형태근로종사자와 유사 하다는 근거를 제시하였다.

해외 사례 역시 프로스포츠선수를 노동자로 인정하는 흐름이 지배적이다. 대표적으로 미국 및 일본 프로야구선 수, 미국 프로농구선수, 유럽 프로축구선수들의 노동조합 결성이 그 예이다. 실제로 유럽사법재판소는 European Court법(이하 $\mathrm{EC}$ 법)이 프로스포츠 관련 사건에도 적용 될 수 있는지에 대해서 (1) "스포츠가 로마조약 제 2 조에 말하는 '경제적 활동'에 해당하는 경우에는 $\mathrm{EC}$ 법의 적용 대상”이 되며, (2) “보수를 받고 노무를 제공하는 프로스 포츠선수 혹은 준프로스포츠선수는 노동자로 인정”된다 고 하였다(Chang, 2008:277). 물론 국내에서는 근로기 준법상 근로자의 개념과 노동조합의 결성 지위로서 근로 자는 명확히 구별되고 있지만, 최근 법원의 판결례는 두 개념을 동일한 것으로 해석하기도 했다(Kwon, 2012). 다음은 미국과 일본 프로야구선수들을 ‘노동자'로 인정한 사례를 다룬 보도 내용이다.

"미국 메이저리그선수노조(MLBPA)의 태생은 1885년까지 거슬러 올라간다. 그러나 당시에는 사교모임 성격이 강했다. 노동조합 성격을 띠기 시작한 것은 1966년 전미금속노조 임 원 출신의 노동전문가 마빈 밀러를 영입하면서부터다. (중 략) 그는 곧바로 최저임금을 6000 달러에서 1만 달러로 올리 는 성과를 올렸고, 1982년까지 위원장을 지내면서 자유계약 제도(FA)를 도입했으며 초상권과 연금 문제 등을 해결했다. 메이저리그선수노조는 1971년 이후 지금껏 다섯 차례 파업 을 단행했고, 메이저리그 사무국은 세 차례 직장폐쇄로 맞섰 
다. 가장 최근의 파업은 1994년 8월부터 1995년 4월까지 이어졌으며, 월드시리즈를 포함해 사상 최초로 전체 포스트 시즌 일정을 무산시키며 샐러리캡(연봉상한제) 도입 저지에 성공했다. 메이저리그는 현재 미국 프로스포츠에서 샐러리 캡이 없는 유일한 리그로 남아 있다. (중략) 일본 프로야구 선수들은 1966년 처음 노동조합 설립을 시도했지만 사무국 의 반대로 무산됐다. 1980 년 일본프로야구선수모임회를 발 족시킨 뒤 서서히 노동조합으로의 전환을 시도했고, 지바 롯 데가 다카하시를 일방적으로 해고한 것을 계기로 1985년 선 수노조(JPBPA)를 출범시켰다. 일본 노동부는 처음에 '프 로야구선수는 노동자로 인정하지 않는다' 는 유권해석을 내 렸으나, 행정소송을 통해 일본 법원이 '노동자의 지위를 갖 는지 여부에 관계없이 노동조합으로서의 단체교섭권을 가지 기 때문에 노조를 설립하는 것이 타당하다' 고 판결하면서 노동조합으로 인정받았다. 이후 92년 자유계약선수제도 도 입을 관철시켰고, 최저연봉 인상, 연금액 증액 등을 이끌어 냈다. 2000년엔 대리인(에이전트) 제도도 도입했다."

- Kim(2009, Dec 3)

이처럼 프로스포츠선수의 근로자성에 관한 학술적 논 의와 해외 사례는 근로기준법상 근로자 또는 특수형태근 로종사자로 바라보는 경향이 지배적이다. 그리고 이러한 경향은 계약의 명칭과 명목상 도급의 형식을 보이더라도 그 '실질'이 사실상 근로관계로 인정된다면 법적 보호가 이루어져야 한다는 우리나라 대법원 판례에서도 동일하 게 발견된다(대법원 2003. 9. 23. 2003두3420; 대법원 2008. 7. 10. 2005다75088). 즉 프로스포츠구단이 계 약의 명목상 도급 형태로 선수를 사용하고 있음에도 불구 하고, 구단과 선수 사이에 '노동의 종속성'이 실질적으로 존재한다면 근로계약관계를 인정할 수 있다는 것이다. 다 음은 계약의 형식과 무관하게 실질적인 노동 형식을 근거 로 근로자성을 인정한 대법원 판례들이다.

"근로기준법상 근로자에 해당하는지는 계약의 형식이 고용 계약, 도급계약 또는 위임계약인지 여부보다 근로제공 관계 의 실질이 근로제공자가 사업 또는 사업장에 임금을 목적으 로 종속적인 관계에서 사용자에게 근로를 제공하였는지 여 부에 따라 판단하여야 한다. 여기에서 종속적인 관계가 있는 지는, 업무 내용을 사용자가 정하고 취업규칙 또는 복무규정 등의 적용을 받으며 업무수행과정에서 사용자가 상당한 지 휘 · 감독을 하는지, 사용자가 근무시간과 근무 장소를 지정 하고 근로제공자가 이에 구속을 받는지, 근로제공자가 스스 로 비품 - 원자재나 작업도구 등을 소유하거나 제 3 자를 고용 하여 업무를 대행하게 하는 등 독립하여 자신의 계산으로 사 업을 영위할 수 있는지, 근로제공을 통한 이윤의 창출과 손
실의 초래 등 위험을 스스로 안고 있는지, 보수의 성격이 근 로 자체의 대상적 성격인지, 기본급이나 고정급이 정하여졌 고 근로소득세를 원천징수하였는지, 그리고 근로제공 관계 의 계속성과 사용자에 대한 전속성의 유무와 정도, 사회보장 제도에 관한 법령에서 근로자로서 지위를 인정받는지 등의 경제적 - 사회적 여러 조건을 종합하여 판단하여야 한다. 다 만 기본급이나 고정급이 정하여졌는지, 근로소득세를 원천 징수하였는지, 사회보장제도에 관하여 근로자로 인정받는지 등과 같은 사정은 사용자가 경제적으로 우월한 지위를 이용 하여 임의로 정할 여지가 크다는 점에서 그러한 점들이 인정 되지 않는다는 것만으로 근로자성을 쉽게 부정하여서는 안 된다" - 대법원 2006. 12. 7. 2004다29736; 대법원 2017. 9. 7. 2017두46899; 대법원 2018. 10. 25. 2015두 51460

이를 종합해보면, 프로스포츠선수는 근로기준법상 근 로자 개념의 핵심 요소인 '노동의 종속성'을 충족하고, 더 나아가 그들의 스포츠 활동은 '생계 유지목적성'을 지니고 있기 때문에 근로자로 바라보아야 한다는 입장이 지배적 이다. 또한, 특수형태근로종사자의 관점에서 프로스포츠 선수는 근로자와 사용자의 성격을 가지는 동시에 노무의 제공이 특정 사업주에게만 종속되어 근로기준법상 근로 자로 해석할 여지가 강하다. 특히, 프로스포츠선수의 근 로자성에 관한 논의는 일부 유명 선수보다는 다수 일반 선수의 관점에서 접근할 필요가 있으며(Kwon, 2018; Kwon, 2012), 이는 프로스포츠선수의 노동사회법적 보 호의 필요성을 더욱 명확하게 한다. 그리고 이러한 접근 은 앞서 확인했듯이 본 연구의 논제인 $\mathrm{FA}$ 보상금제도가 소득이 낮고 팀 내 입지가 좁은 선수들에게 큰 영향을 미 친다는 점에서 상당한 의미가 있다.

\section{직업(직장)선택 자유의 관점에서 바라본 $\mathrm{FA}$ 보상금제도}

앞서 전개한 프로스포츠선수의 근로자성에 대한 논의 는 본 연구 대상인 $\mathrm{K}$ 리그 선수와 그 계약이 노동사회법의 보호 테두리 안에 있다는 점을 보여준다. 따라서 본 장에 서는 헌법에서 규정한 직업 자유와 관련 법률의 관점에서 $\mathrm{FA}$ 보상금제도를 비판적으로 고찰하고, 다양한 법리적 해석과 학술적 의의를 도출하고자 한다. 


\section{"모든 국민은 직업선택의 자유를 가진다." - 「헌법」 제2 장 제 15 조}

"근로자의 직업선택의 자유와 근로의 권리가 확보되도록 할 것” - 「고용정책 기본법」제1장 제3조의 1

위에 제시한「헌법」제 2 장 제 15 조와 관련 법률인「고 용정책 기본법」제 1 장 제 3 조의 1 은 모든 국민의 직업선 택의 자유를 보장하고 있다. 물론 헌법이 보장하는 직업 의 자유는 절대적인 것이 아니며 경우에 따라「헌법」제 37 조 제 2 항에 근거하여 법률로 제한할 수 있다. 이 조항 에 따르면, "국민의 모든 자유와 권리는 국가안전보장, 질 서유지 또는 공공복리를 위하여 필요한 경우에 한하여 법 률로써 제한할 수 있다." 따라서 헌법에 의해 보장된 직업 자유의 보호범위를 명확히 하기 위해서 직업의 개념과 직 업 자유의 내용을 살펴보고, 직업으로서 프로축구선수와 법적 보호 내용을 이해할 필요가 있다.

\section{직업의 개념과 프로축구선수}

먼저 직업이란 인간이 삶의 정신적·물적 기초를 마련 하기 위해 지속적으로 행하는 경제적 소득활동을 의미하 며, 그 개념은 역사와 제도를 통해 확립된 전통적인 직업 형태 또는 사회적·경제적 여건 속에서 법적으로 승인된 직업상에 의해 파악될 수 있다(Kwon, 2018). 그러나 직 업의 자유에 의해 보호되는 직업은 새로운 사회적 변동을 통해 생성되거나 개인의 창의성에 의해 고안되는 비전형 적인 직업의 형태까지도 포괄할 수 있는 개방적 성질의 개념이어야 한다(Tettinger, 2003).

무엇보다 헌법에 의해 직업 자유가 보호되는 직업은 '공공무해성(Chong, 2016; Hur, 2007; Kay, 2007; Kwon, 2010)'과 '지속성과 생활수단성의 의미 (Tettinger, 2003; Wieland, 2004)'가 개념적 요소로 요구된다. 여 기서 공공무해성은 사회적 무해성으로 불리기도 하며, '법에 의해 금지되지 아니한 활동'을 의미한다(Pieroth, Schlink, Kingreen \& Poscher, 2015). 그러나 '헌법상 금지되지 아니한 직업'이나 ‘허용된 직업'이라는 표현은 입법자에 의해 직업 자유의 공동화를 초래할 수 있기 때 문에 일반적으로 '공공에 해가 되지 않는 활동' 또는 '헌법 의 인간상에 반하지 않는 활동’으로 대체하는 경향이 있
다(Hur, 2007; Kwon, 2010). 공공무해성의 관점에서 프로축구선수의 활동(훈련 및 경기출전)이 공공 또는 사 회적으로 해가 되지 않는 활동이라는 점에 이견이 없을 것이다. 더 나아가 헌법에서 규정한 인간상에 반하지 않 는 활동으로 헌법에 의해 직업 자유가 보호되는 직업으로 이해할 수 있다.

다음으로 '지속성'은 일정 기간이나마 계속적인 직업 활동의 의사가 있다면 인정될 수 있다(Kwon, 2018). 헌 법재판소 역시 지속성에 대해 "주관적으로 활동의 주체가 어느 정도 계속적으로 해당 소득활동을 영위할 의사가 있 고, 객관적으로도 그러한 활동이 계속성을 띨 수 있으면 족하다”고 판결하였다(헌재 2003. 9. 25. 2002헌마 519). 또한, '생활수단성'은 생계를 유지하기 위한 소득활 동으로 겸업이나 부업도 직업의 개념에 포함될 수 있으며 (헌재 2003. 9. 25. 2002헌마519), 반면에 취미활동이 나 여가선용, 무상의 봉사활동 등은 생활수단성이 인정되 지 않아 직업으로 보기 어렵다(헌재 2002. 12. 18. 2001 헌마370). 같은 맥락에서 Jeong(2010)은 스포츠선수의 활동은 그들의 삶의 기초를 마련하기 위해 '지속성'과 '생 활수단성'을 보이고 있기 때문에「헌법」제 15 조에서 규정 한 직업으로서 그 보호영역에 포함된다고 주장하였다. 그 리고 이러한 주장은 스포츠 활동이 단순히 행하는 것이 아닌 보는 스포츠, 즉 스포츠 상업화의 발달에 근거를 두 고 있다(Jeong, 2004).

공공무해성, 지속성, 생활수단성이라는 개념 요소 외 에도 프로스포츠선수를 헌법 및 관련 법률에서 보호하는 직업으로 인정할 수 있는 근거로는 한국표준직업분류와 이 분류를 법리적 해석에 활용한 대법원 판례가 있다. 2018년 대법원은 배달대행업체의 배달원이「산업재해보 상보험법」에서 말하는 근로자, 즉 근로기준법상 근로자 에 해당하는지에 대한 판결에서 한국표준직업분류표의 세분류에 근거하여 택배원(92221)으로 보는 것이 타당 하다고 하였다(대법원 2018. 4. 26. 2016두49372). 국 제노동기구의 국제표준직업분류에 근거한 '제7차 한국표 준직업분류'에 의하면, 프로축구선수는 전문가 및 관련 종 사자(2)-문화예술스포츠 전문가 및 관련직(28)-스포츠 및 레크리에이션 관련 전문가(286)-직업 운동선수(2862)-직 업 운동선수(28620)으로 분류된다(Statistics Korea, 2017). 그리고 직업 운동선수의 주요 업무로는 체력훈련 
과 기술훈련, 새로운 전술·전략 개발, 자신 및 경쟁상대에 대한 조사·분석, 경기출전 등을 상세히 기술하고 있다.

이를 종합해보면, 헌법에 의해 직업 자유가 보호되는 직업은 공공무해성, 지속성, 생활수단이라는 개념 요소 를 충족해야 하는데, 프로스포츠선수는 이들 개념 요소를 충족하고 있다는 학계 해석이 지배적이다. 직업의 개념적 요소뿐만 아니라 한국표준직업분류를 그 법적 보호 대상 의 근거로 채택한 대법원 판례는 제 7 차 한국표준직업분 류에 의해 직업 운동선수(28620)로 분류된 프로축구선 수를 근로기준법상 근로자로 판단하는데 무게를 실어준 다. 이러한 관점에서「헌법」제2장 제 15 조가 보호하고 있는 직업 자유는 프로축구선수에게도 무관하지 않으며, 따라서 직업 자유의 내용(또는 적용 범위)을 바탕으로 $\mathrm{FA}$ 보상금제도에 관한 법제도적 고찰을 이어갈 필요가 있다.

\section{직업 자유의 내용(적용 범위)과 $\mathrm{FA}$ 보상금제도}

그렇다면 헌법이 보호하는 직업 자유의 내용은 무엇이 며, 그 범위는 어디까지 인가. 학자마다 용어 사용에 차이 가 있을 뿐 실질적인 의미는 큰 틀에서 유사하다. Kwon(2018:22)은 「헌법」제15조에서 규정한 직업선택 의 자유는 "개인이 종사하고자 하는 직업을 결정할 수 있 는 자유뿐만 아니라 그가 선택한 직종에서 자신이 원하는 방법이나 형태로 자유롭게 직업 활동을 수행해나갈 수 있 는 자유"까지 포함해야 한다는 입장을 견지하면서, "자신 이 선택한 직업에 종사하고 그 직업을 유지할 수 있는 권 리가 인정되지 않는다면, 직업의 선택권을 보장한다는 것 은 무의미하다"고 하였다. 그리고 이러한 관점에서 직업 자유의 내용을 '좁은 의미의 직업선택의 자유', '직업수행 의 자유', '직장선택의 자유'로 구분하였다(Kwon, 2018). $\operatorname{Lim}(2016)$ 도 표현에 차이는 있지만, '직업결정의 자유', '직업수행의 자유', '직업이탈과 전직의 자유'라는 분류를 채택하였다.

다른 헌법학자들 역시 '좁은 의미의 직업선택의 자유' 뿐만 아니라 '직업수행의 자유', '전직의 자유', '직장선택 의 자유', '직업교육장선택의 자유', '무직업의 자유' 등을 포함하는 넓은 개념으로 이해하고 있다(Han, 2017; Jung, 2014; Sung, 2017). 헌법재판소 판례에서도 직
업 자유의 내용을 직업과 관련된 종합적이고 포괄적인 자 유로 해석하였다(헌재 1995. 7. 21. 94헌마 125 ; 헌재 2002. 11. 28. 2001헌바50). 이는「헌법」제 15 조에서 규정한 직업선택의 자유를 문리적 해석을 넘어 현대사회 의 헌법적 상황에 맞게 해당 조항을 개정할 필요가 있음 을 의미한다(Pyo, 2009). 실제로 2018년 3월 26일에 발 의된 대통령 헌법개정안은 종전의 조항에서 '선택'을 제외 하여, "모든 국민은 직업의 자유를 가진다"로 새롭게 규정 하였다. 이는 '직업선택의 자유'에서 '직업의 자유'로 개정 함으로써 직업과 관련된 포괄적인 자유를 보호하고, 시대 적 요구를 반영한 것이다.

본 연구에서도 같은 관점을 견지하면서 직업 자유의 포괄적 개념 중 '직장선택의 자유'에 보다 초점을 두고자 한다. FA보상금제도가 계약기간이 만료된 프로축구선수 의 이적, 즉 $\mathrm{FA}$ 선수의 구단(직장) 선택의 자유를 제한하 고 있기 때문이다.「헌법」제 15 조에서 규정한 직업선택 의 자유는 직장을 자유롭게 선택할 수 있는 권리로서 고 용된 형태의 종속적 직업 활동을 자유롭게 선택하고 행사 한다는 것을 의미한다(Kwon, 2018). Lee(2014:408) 역시 "근로자가 더 나은 근로조건을 가진 직업으로 옮기 고자 할 때에도 당연히 국가의 방해를 받지 않고 전직할 권리를 인정받아야 한다”고 주장하였다. 이는 단순히 학 계의 해석에 그치지 않고 헌법재판소 판례에서도 동일한 법리적 해석을 보이고 있다. 다음은 「헌법」제 15 조 직업 선택의 자유가 '직장선택의 자유'를 포괄한다고 보는 헌법 재판소 판결문이다.

"헌법 제15조가 보장하는 직업선택의 자유는 직업 '선 택' 의 자유만이 아니라 직업과 관련된 종합적이고 포괄적인 직업의 자유를 보장하는 것이다. 또한 직업의 자유는 독립적 형태의 직업 활동뿐만 아니라 고용된 형태의 종속적인 직업 활동도 보장한다. 따라서 직업선택의 자유는 직장선택의 자 유를 포함한다. (중략) 직장선택의 자유는 특히 근로자들에 게 큰 의미를 지닌다." - 헌재 2002. 11. 28. 2001헌바50

\footnotetext{
"「헌법」 제15조에 따라 모든 국민은 직업선택의 자유를 가 진다. 따라서 국민은 누구나 자유롭게 자신이 종사할 직업을 선택하고, 그 직업에 종사하며, 이를 변경할 수 있다. 이에 는 개인의 직업적 활동을 하는 장소 즉 직장을 선택할 자유 도 포함된다." - 헌재 1989. 11. 20. 89헌가102
} 
이처럼「헌법」제 15 조에서 규정한 직업의 자유는 협의 의 의미에서 '직장선택의 자유'를 포괄하고 있다. 여기서 중요한 점은 프로스포츠선수에게 직장선택의 자유는 '이 적의 자유'로 이해할 수 있는데 특히, FA선수의 이적의 자유가 그것이다. Chang(2011a)은 프로스포츠선수의 이적에 관한 법적 문제로 'FA자격 취득 요건'과 'FA선수 이적에 대한 보상'을 논의하였다. 여기서 FA자격 취득 요 건은 차치하더라도, $\mathrm{FA}$ 선수 이적에 대한 보상 문제는 본 연구의 논제인 FA보상금제도와 유사하다는 점에서 비교 논의가 가능하다. Chang(2011a)은 제한적 FA선수에 대한 보상제도가 계약이 만료된 선수의 이적의 자유를 허 용하는 FA제도의 본래 의미를 무색하게 하고, 선수의 권 리를 과도하게 침해하고 있다고 주장하였다. 마찬가지로 프로야구를 대상으로 한 다른 연구에서도 가장 문제가 심 각한 규정으로 보상제도를 언급하였으며 (Han \& Jung, 2012), FA선수의 이적을 실질적으로 제한한다는 점에서 $\mathrm{K}$ 리그 FA보상금제도과 무관하지 않다. Chang(2009)의 연구에서도 선수계약제도가 직업 자유에 위배된다는 법 리적 해석을 내놓았다. 그는 국내 프로야구의 보류선수제 도가 선수들의 이적을 금지시키고 특정 구단에의 전속성 이라는 반작용을 가져온다는 점에서「헌법」제 15 조에서 규정한 직업 자유를 본질적으로 침해한다고 하였다.

국내 연구의 법리적 해석과 국가인권위원회 결정례뿐 만 아니라 실제 해외 사례에서도 계약이 만료된 선수에게 이적료나 보상금을 요구하여 이적을 제한하는 행위는 위 법으로 간주해왔다. 대표적으로 1995년 유럽사법재판소 의 보스만 판결이 그 예이다. 보스만 판결을 들여다보기 전에 로마조약 제 1 장 제 48 조(현 제 39 조)와 당시 벨기에 축구협회(이하 URBSFA)의 이적제도를 간략히 살펴볼 필요가 있다. 먼저 로마조약이란 1957년 3월 25일 로마 에서 유럽경제 공동체 회원국에 의해 서명된 후 1958 년 1 월 1일 발효된 조약이다.「로마조약」제48조(현 39조) (1)항에 따르면 "노동자의 이동의 자유는 공동체 내에서 보장된다”고 규정하고 있는데, 당시 URBSFA의 이적제 도가 이 조항을 위반한 것이 보스만 판결의 요지이다. 벨 기에 프로축구선수였던 보스만은 소속 구단과의 계약이 만료된 후 다른 구단으로 이적을 시도하였으나 원 소속 구단의 과도한 이적료 요구로 인해 결국 이적에 실패하였 고, 이후 벨기에 지방법원에 원 소속 구단과 URBSFA를
상대로 손해배상 청구, URBSFA 및 유럽축구연맹을 상 대로 이적료 제도의 폐지를 요구하였다. 결론적으로 해당 사건은 유럽사법재판소로 이송되었으며, 「로마조약」제 1 장 제 48 조(현 제39조)에 근거하여 보스만의 손을 들어 주었다. 이후 보스만 판결은 국제축구연맹과 유럽축구연 맹의 이적 제도의 개정으로 이어졌으며, 오늘날 스포츠선 수의 이적의 자유를 보장한다는 의미에서 '보스만 룰'로 통용되고 있다. 다음은 당시 유럽사법재판소 판결 내용의 일부이며, Chang(2008)의 연구에서 재인용하였음을 밝 힌다.

\footnotetext{
"(1) EU회원국의 선수가 계약만료 후 구단을 이적하는 경 우에, 이적금을 요구하는 것은 선수의 이동을 제한하는 것이 므로, 노동자의 자유이동에 대한 제한이 되기 때문에 로마조 약 제48조에 반한다. (2) 이적제도는 (ㄱ)클럽 간의 재정적 균 형, 니경기력의 균형, (ㄷ)유망선수의 육성 등의 이유로 정당 화 될 수 없으며, 이러한 점은 노동자의 이동의 자유를 침해 하지 않는 방법에 의해 실현될 수 있다."
}

이를 종합해보면, 선행연구와 헌법재판소 판례 그리고 해외 사례는 스포츠선수의 이적의 자유를 앞서 살펴본 '직장선택의 자유'와 동일한 것으로 간주하고, 따라서「헌 법」제 15 조에서 규정한 직업 자유의 포괄적 개념 중 '직 장선택의 자유'에 위배된다는 문제의식을 견지하고 있다. 같은 맥락에서 $\mathrm{K}$ 리그 $\mathrm{FA}$ 보상금제도는 계약이 만료된 $\mathrm{FA}$ 선수에게 보상금을 요구하여 다른 구단으로의 자유로 운 이적, 즉 직장선택의 자유를 제한한다는 점에서 위헌 적 요소를 내포한다고 할 수 있다.

\section{행복추구권과 $\mathrm{FA}$ 보상금제도}

"모든 국민은 인간으로서의 존엄과 가치를 가지며, 행복을 추구할 권리를 가진다. 국가는 개인이 가지는 불가침의 기본 적 인권을 확인하고 이를 보장할 의무를 진다." - 「헌법」 제2장 제 10 조

앞서 직업의 개념과 직업으로서 프로축구선수, 직업 (직장)선택의 자유의 내용을 바탕으로 FA보상금제도에 관한 법리적 해석을 제공하였다. 본 연구는 이 과정에서 직업의 자유가 행복추구권과 밀접한 관련이 있음을 확인 했다. 직업의 자유를 비롯해 헌법이 규정한 모든 기본권 은 행복추구권 실현의 수단이나 다름없으며, 따라서 행복 
추구권은 모든 기본권의 기초가 되는 근본 가치를 표현한 것이기 때문이다(Cha et al., 2016).

이에 $\operatorname{Kim}(2016)$ 은 「외국인근로자의 고용 등에 관한 법률」제 4 장 제 25 조가 직업선택의 자유로서 직장선택의 자유를 과도하게 제한하여「헌법」제 2 장 제 10 조에서 보 장하는 인간으로서의 존엄과 행복추구권을 침해한다는 법리적 해석을 내놓았다. 이 해석의 요지는 근로자가 사 업장을 변경하기 위해서는 원칙적으로 사업주의 동의를 받아 근로계약을 해지해야 한다는 규정에 있으며, 이는 본 연구에서 주목한 FA보상금제도와 유사한 성격을 지 니고 있다. 동 법률 제4장 제 25조 (1)항의 1에 따르면, 외 국인근로자는 "사용자가 정당한 사유로 근로계약기간 중 근로계약을 해지하려고 하거나 근로계약이 만료된 후 갱 신을 거절하려는 경우”에 사업장 변경을 신청할 수 있는 데, 이는 사업장 변경의 권한이 전적으로 사용자에게 부 여된 것이다. 이 규정과 관련하여 헌법재판소 역시 직장 선택의 자유를 행복추구권과의 밀접한 관계로 보면서 외 국인근로자의 제한적 자유를 인정하였다.

"직업의 자유 중 이 사건에서 문제되는 직장 선택의 자유는 인간의 존엄과 가치 및 행복추구권과도 밀접한 관련을 가지 는 만큼 단순히 국민의 권리가 아닌 인간의 권리로 보아야 할 것이므로 외국인도 제한적으로라도 직장 선택의 자유를 향유할 수 있다고 보아야 한다." - 헌재 2011. 9. 29. 2007헌마1083

같은 맥락에서 스포츠선수의 이적의 자유를 행복추구 권 관점에서 판단한 국내 사례도 있다. 국가인권위원회는 $\mathrm{A}$ 시청 역도팀이 소속 선수의 이적 동의서를 거부한 사건 에 대해서 헌법이 보장하고 있는 자기운명결정권 또는 행 복추구권, 직업선택의 자유를 침해한다고 결정하였다. 다음은 이와 관련된 국가인권위원회의 결정례 내용이며, 비록 프로스포츠선수는 아니지만 '직업선택의 자유'의 관 점에서 선수 이적 문제를 다맀다는 점은 본 연구에도 상 당한 의미가 있다.

"체육선수는 선수로서 활동할 때 비로소 그 존재의 가치와 의의를 발현할 수 있게 되는 것이며, 보다 더 나은 대우를 받으며 운동에 전념할 수 있는 기회를 선택하고자하는 것은 헌법이 보장하고 있는 기본적 권리이다. 피진정인이 진정인 에게 이적동의서를 발급하지 않음으로써 진정인이 무등록선
수가 되게 하는 것은 체육선수로서 가지는 자유와 권리의 본 질적 내용을 침해하는 것이며, 법령에 근거 없이 체육계의 묵시적인 관행 및 사전협의가 없었다는 이유로 이적동의서 발급을 거부할 수는 없다고 할 것이다. (중략) 체육계의 묵 시적인 관행 및 사전 협의가 없었다는 등의 이유로 이적동의 서 발급을 거부한 행위는 헌법 제10조 및 제 15 조가 보장하 고 있는 운동선수의 자기운명결정권 내지 행복추구권, 직업 선택의 자유 등 진정인의 인권을 침해하는 것으로 판단되므 로 이적동의서를 발급해주도록 권고(한다.)" - 국가인권위 원회 2003. 6. 16. 03진인411

마찬가지로 FA보상금제도 하에서 계약이 만료된 선수 의 사업장 변경(여기서는 다른 구단으로의 이적)에 대한 권한은 전적으로 원 소속 구단이 가지게 되는데, 그 중심 에는 명목상 보상금이라는 사업주(여기서는 원 소속 구 단)의 동의 여부가 존재한다. 다시 말해, 원 소속 구단이 보상금을 포기하지 않는 한 FA선수의 이적의 자유는 허 용되지 않는다는 것이다. 그러나 앞서 살펴본 헌법재판소 판례와 국가인권위원회 결정례는 직업 (직장)선택의 자유 가「헌법」제 2 장 제 10 조에서 보장하는 행복추구권과 밀 접한 관련이 있다는 법리적 해석을 내림으로써 FA보상 금제도의 위헌 가능성을 제시하고 있다.

본 연구는 이러한 법리적 해석을 근거로 FA보상금제 도에 관한 전면 개정 또는 폐지에 대한 필요성을 제고하 고, 이와 관련된 후속 연구 및 정책 결정 과정에 판단 자 료를 제공한다는 점에서 의의가 있다. 그도 그럴 것이 헌 법적 관점에서 기본권은 대국가적 방어권과 객관적 가치 질서의 성격을 지닌다는 점에서 프로스포츠단체가 공적 기관이 아닌 사적 단체일지라도 국가는 개인의 기본권 보 호 의무를 이행해야 할 것이다(Kim, 2002).

\section{맺음말}

우리가 흔히 접하고 있는 프로스포츠선수들의 삶은 화 려하기 그지없다. 높은 소득 수준, 많은 팬들의 사랑과 관 심 그리고 경우에 따라 국가를 대표하는 영예까지 일반 대중에게 부러움과 선망의 대상이 되기도 한다. 대표적으 로 손흥민, 류현진, 김연아 선수가 그 예이다. 그러나 이 들은 프로스포츠선수 더 나아가 아마추어선수까지 고려 했을 때 매우 극소수에 불과하며, 다수의 일반 선수들은 
언론의 사각지대에서 잘 드러나지 않고 있다. 일부 선수 의 화려함에 다수 선수들의 실제적 삶을 들여다볼 기회가 상대적으로 적은 것이 사실이다.

문제는 일부 유명 선수와 달리, 다수 일반 선수들은 각 연맹과 소속 구단의 정책 및 제도로부터 소외된 경우가 있음에도 불구하고 그동안 학계(특히, 체육학계)의 지적 관심은 소극적이었다는 점이다. 오히려 일반 법학자들이 스포츠 관련 법제도적 문제에 대해 비판적 관점을 견지해 왔으며, 실제 현장의 목소리에 귀 기울이는 노력은 일부 기자들의 몫이었다.

본 연구는 이러한 문제의식을 바탕으로 국내 프로축구

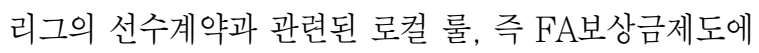

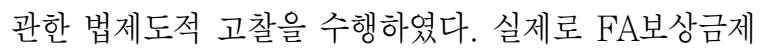
도는 일부 언론 보도를 통해 오랜 기간 개정 또는 폐지의 필요성이 제기되었음에도 이를 뒷받침할(또는 지지할) 학계의 법리적 해석은 시도된 적이 없었다. 이에 본 연구 는 FA보상금제도를 어떠한 헌법적 법리와 내용에 적용 할 수 있는지 살펴보고, 향후 제기될 수 있는 문제와 그 개선방향을 모색하였다.

이를 위해 첫째, 프로스포츠에서 자유계약 $(\mathrm{FA})$ 과 이

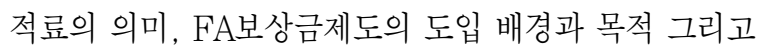

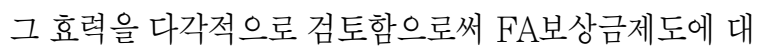
한 전반적인 이해를 선행하였다. 둘째, 프로축구선수의 근로자성에 대한 법적 개념을 살펴봄으로써 FA보상금제 도에 대한 법제도적 고찰의 타당성을 확보하였다. 셋째, 헌법에서 보장하는 기본권의 관점에서 $\mathrm{FA}$ 보상금제도의 문제점을 들여다보았다. 구체적으로 직업의 개념, 직업 으로서 프로축구선수, 직업의 자유의 내용(적용 범위)을 다각적 자료(헌법 조문 및 관련 현행 법률, 헌법재판소 및 대법원 판례, 국가인권위원회 결정례, 프로스포츠선수 계약 관련 문헌, 해외 프로스포츠리그 정관 및 규정, 프로 스포츠선수 계약 관련 유럽사법재판소 판례)로부터 비교 분석하였다.

결론적으로 $\mathrm{FA}$ 보상금제도는 「헌법」제 2 장 제 15 조 직 업(직장)선택의 자유와 동법 제 2 장 제 10 조 행복추구권 을 침해한다는 법리적 해석이 가능하다. 먼저 국내 연구 와 헌법재판소 판례 그리고 해외 사례는 스포츠선수의 이 적의 자유를 '직장선택의 자유'와 동일한 것으로 간주하 고, 따라서「헌법」제 15 조에서 규정한 직업 자유의 포괄
적 개념 중 '직장선택의 자유'에 위배된다는 문제의식을 견지하였다. 같은 맥락에서 $\mathrm{K}$ 리그 $\mathrm{FA}$ 보상금제도는 계약 이 만료된 선수에게 보상금을 요구하여 다른 구단으로의 자유로운 이적, 즉 직장선택의 자유를 제한한다는 점에서 위헌적 요소를 내포한다고 할 수 있다.

다음으로 FA보상금제도 하에서 계약이 만료된 선수의 사업장 변경(여기서는 다른 구단으로의 이적)에 대한 권 한은 전적으로 원 소속 구단이 가지게 되는데, 그 중심에 는 명목상 보상금이라는 사업주(여기서는 원 소속 구단) 의 동의 여부가 존재한다. 다시 말해, 원 소속 구단이 보 상금을 포기하지 않는 한 FA선수의 이적의 자유는 허용 되지 않는다는 것이다. 이는 직업(직장)선택의 자유가 「 헌법」제 2 장 제 10 조에서 보장하는 행복추구권과 밀접한 관련이 있다는 헌법재판소 판례와 국가인권위원회 결정 례를 비추어볼 때, FA보상금제도의 위헌 가능성을 제기 할 수 있다. 본 연구는 이와 같은 법리적 해석을 근거로 $\mathrm{FA}$ 보상금제도에 관한 전면 개정 또는 폐지에 대한 필요 성을 제고하였다.

한편, 한국프로축구연맹은 최근 이사회를 통해 2021 년 시즌부터 $\mathrm{FA}$ 보상금제도를 폐지한다고 발표하였다 (Lee, 2019, Dec. 2). 이는 본 논문이 견지한 비판적 관 점과 제도의 문제점을 현장에서도 수용한 것으로 이해할 수 있으며, 긍정적 변화임에는 틀림없다. 그러나 FA보상 금제도에 대한 연구는 여전히 전무하며, 언제든지 쟁점이 될 수 있는 유사규정에 관한 법리적 해석과 학술적 근거 가 필요한 실정이다. 따라서 특정 제도가 폐지되었거나 추후 폐지될 예정이더라도 그 제도에 대한 사후 평가는 여전히 실천적 의의를 지니고 있으며, 향후 유사 기관의 정책결정과정과 후속 연구에 기초 자료(근거)로서 학술 적 가치가 있다.

반면에 이러한 기여에도 불구하고, 본 연구는 FA보상 금제도의 구체적인 개선방안이나 폐지에 따른 정책적 실 효성을 제시하는 데는 한계를 지니고 있다. 또한, 본문에 서 밝혔듯이 선수(특히, 낮은 소득 수준과 팀 내 입지가 좁은 선수)의 입장에서 제도에 관한 비판적 관점을 견지 하였기 때문에 $\mathrm{FA}$ 보상금제도와 연맹 및 구단의 이해관 계에 대해서는 심도 있게 다루지 못한 부분도 있다.

따라서 후속 연구에서는 선수뿐만 아니라 구단, 연맹, 소비자 등 다양한 관점에서 $\mathrm{FA}$ 보상금제도에 대한 법리 
적 해석을 보완하고, 더 나아가 제도의 개선방안과 정책 적 실효성을 제공할 필요가 있다. 끝으로 학계에서는 현 장에서 쟁점이 되고 있는 스포츠 계약 관련 규정에 지속 적인 관심과 지적 노력을 기울일 필요가 있다. 예컨대, 최 근 사회적으로 논란이 된 $\mathrm{K}$ 리그의 '선수계약양도(한국프 로축구연맹 규정집 제2장 제 23 조)'를 꼽을 수 있다.

\section{참고문헌}

Ahn, B. H. (2018). A legal study on the controversy over introduction of salary ceiling for professional baseball FA players. The Journal of Sports and Entertainment Law, 21(4), 3-20.

Ahn, I. S. (2012, Dec. 18). Open FA market $\cdots$ Busan is 'out of interest'. The Kookje Daily News. Retrieved from http://www.kookje.co.kr

Ahn, Y. J., \& Cho, N. K. (2018, Nov. 7). Where will K league go?. Best Eleven. Retrieved from http://www.besteleven.com

Bae, J. S., Park, J. H., Chung, J. M., \& Cho, K. M. (2018). Seeking for development of Korean professional baseball FA system through grounded theory. The Korean Society of Sports Science, 27(2), 505-517.

Cha, B. J., Yoon, J. W., \& Yoon, J. Y. (2016). Now again, constitutional law. Ggyeonggi: Logopolis.

Chang, J. S. (2009). Special issues: Various issues concerning the professional baseball players` contracts. The Journal of Sports and Entertainment Law, 12(4), 219-253.

Chang, M. (2008). Transfer systems in European football and the Bosman ruling of the European Court of Justice. The Yonsei law review, 18(1), 245-294.

Chang, M. (2011a). Legal issues of sports player transfer upon player contract's expiration: focused on compensation for free agent's transfer. Chosun Law Journal, 18(3), 113-141.

Chang, M. (2011b). Legal issues in termination of player contract by club: Focused on waiver clause. The Journal of Sports and Entertainment Law, 14(4), 33-57.

Chang, Y. C., \& Kim, P. S. (2017). Qualitative study on the contract theory and contractual relationship between Korean professional players and clubs. Korean Journal of Sport Studies, 56(1), 319-329.

Chong, J. S. (2016). Verfassungslehre. Seoul: Pakyoungsa.
Chung, T. R. (2017). A legal interpretation on the athlete transf er contract a fraud action of professional baseball team is included. Korean Journal of Sport Management, 22(1), 19-29.

Deloitte Sports Business Group. (2020). Football money league: eye on the prize. London: Deloitte.

Free Agency. (n.d.). In Major League Baseball glossary. Retrieved from http://m.mlb.com/glossary

Free Agency. (n.d.). In Oxford Learner's Dictionaries. Retrieved from https://www.oxfordlearnersdicti onaries.com

Han, S. I., \& Jung, D. J. (2012). Study on the problems of professional baseball player contract in Korea and direction for improvement. The Journal of Sports and Entertainment Law, 15(3), 127-152.

Han, S. W. (2017). Constitution studies. Gyeonggi: Bobmunsa.

Heo, J. H. (2013, Dec. 23). Frozen transfer market, non-mainstream K leaguers' heavy wintering. OSEN. Retrieved from http:// osen.mt.co.kr

Hill, J. R., \& Spellman, W. (1983). Professional baseball: The reserve clause and salary structure. Industrial Relations: A Journal of Economy and Society, 22(1), 1-19.

Hur, Y. (2007). Korean constitutional law. Seoul: Pakyoungsa. Im, J. L. (2019). Labor law. Seoul: Pakyoungsa.

Jeong, S. J. (2004). A study on the protection of fundamental rights for sports players. Doctoral dissertation. Kyung Hee University.

Jeong, S. J. (2010). Sports player's right for occupation. The Journal of Sports and Entertainment Law, 13(3), 83-105.

Jung, Y. H. (2014). Criteria for judging the violation of freedom of occupation. Seoul: Constitutional Research Institute of Constitutional Court of Korea.

Kay, H. Y. (2007). Constitution studies. Seoul: Pakyoungsa.

Kim, B. H. (2011). The binding force of the player contract. Journal of Theory and Practice of Private Law, 15(1), 115-145.

Kim, C. Y. (2016). Administrative law. Seoul: Gosi-Law.

Kim, D. K., \& Park, B. Y. (2014). Study on the Efficient Marketing Mix (7P) Management of K League Clubs. Korean Journal of Sport Management, 19(6), 133-155.

Kim, E. K. (2009). Several legal issues concerning Korean professional Sports: Focusing on the draft system in Korean football league. The Journal of Sports and Entertainment Law, 13(2), 145-158.

Kim, H. (2017, Aug. 4). FA compensation system-unfair release, shadow of $\mathrm{K}$ league. Kimhwan Column. Retrieved from https://sports.news.naver.com/kfootball/news/read.nhn?oid= 
516\&aid $=0000000090$

Kim, H. B. (2018). Labor law. Seoul: Pakyoungsa.

Kim, H. D. (2009). Legal access to contract of professional sports player: Relationship between regulations by anti-trust laws and protection under labor laws. Journal of Economic Law, 8(2), 177-206.

Kim, J. H. (2014, Dec. 22). Enriched K league transfer market, 200 FA players announced. The Sports Chosun. Retrieved from http://sports.chosun.com

Kim, J. W. (2019, Jul. 10). Nam and Kim trade, is it possible to transfer without the player's consent?. Ohmynews. Retrieved from http://star.ohmynews.com

Kim, K. B. (2012, Jan. 6). Kleague players' salary, bubble or market principle?. The Kyunghyang Shinmun. Retrieved from http://sports.khan.co.kr/

Kim, K. S. (2016). Reshaping the employer-employee relations hip in response to the diversification of employment types. Doctoral dissertation. Seoul National University.

Kim, M. C. (2013). Study on Managerial Background of Provincial and Municipal Professional Soccer Teams by Analyzing Financial Ratios. Korean Journal of Sport Management, 18(6), 87-101.

Kim, N. J. (2016). Working place transfer right of foreign workers for the human rights security. Law Review, 16(2), 47-71.

Kim, S. L. (2019, Aug. 1). "Korean football has many institutions to improve” said secretary general of KFPA. Ilyo. Retrieved from http://ilyo.co.kr

Kim, Y. H. (2009, Dec. 3). US and Japan recognize baseball player workers $\cdots$ Union is a communication channel. The Hankyoreh. Retrieved from http://www.hani.co.kr

Kim, Y. S. (2002). Legal issues of the draft system. The Journal of Sports and Entertainment Law, 3, 63-86.

Korea Baseball Organization. (2018). 2018 KBO regulation. Seoul: Korea Baseball Organization.

Korea Professional Football League. (2017). K league regulation. Seoul: Korea Professional Football League.

Korea Professional Football League. (2019). 2019 K league players' annual salary by clubs. Seoul: Korea Professional Football League.

Kwon, G. B. (2018). Analyses on the constitutional court decision concerning freedom of occupation. Ajou Law Review, 12(2), $11-41$

Kwon, H. (2012). Berufssport und arbeitsrecht. LAW REVIEW,
53(4), 237-261.

Kwon, Y. H. (2018). Improvement of the act for the application of the industrial accident compensation insuran ce act for professional sportsmen. Legislation, 10, 86-131.

Kwon, Y. S. (2010). Verfassungslehre. Gyeonggi: Bobmunsa.

Lee, H. K. (2018). Player contracts and player agent systems in the Korean professional baseball league. The Journal of Sports and Entertainment Law, 21(4), 66-80.

Lee, H. S. (2004). A review of freedom and substantial security for occupational options in each country from the perspective of labor law. The Journal of Comparative Private Law, 11(4), 387-417.

Lee, Y. H. (2019, Dec. 23). 228 people acquired K League FA in 2020. Yonhap News Agency. Retrieved from https://ww w.yna.co.kr

Lee, Y. H. (2019, Jul. 9). Kleague transfer regulations, whose side?. Yonhap News Agency. Retrieved from http://www.yna.co.kr

Lee, Y. S. (2019, Dec. 2). The Korea Professional Football League decided to abolish FA compensation system from 2021. The Daily Sports Seoul. Retrieved fromhttp://www.sportsseoul.com/ news/read/856388

Lim, J. B. (2016). Freedom of occupation and the principle of proportionality. Korean Lawyers Association Journal, 65(9), 367-401.

Local Rule. (n.d.). In Oxford Dictionaries. Retrieved from https://languages.oup.com

Local Rule. (n.d.). In The USLegal Dictionary. Retrieved from https://definitions.uslegal.com

Ministry of Culture, Sports and Tourism. (2019). 2017 Sport industry white paper. Sejong: Ministry of Culture, Sports and Tourism.

Mo, K. Y. (2015, Dec. 22). 219 Players acquired FAqualificati ons. Kukminilbo. Retrieved from http://news.kmib.co.kr

Myung, W. S. (2018). Korean professional football league's exodus: Player migration to China, the Middle East and Southeast Asia. Doctoral dissertation. Yonsei University.

Myung, W. S., \& Lee, J. Y. (2018). The changes of paradigm in sport labor migration and its significance: Focused on Korean footballers. Korean Journal of Sport Studies, 57(5), 105-123.

Myung, W. S., \& Won, Y. S. (2019). Korean footballers' exodus and its factors: Player migration to China and the Middle East. Korean Journal of Sport Science, 30(1), 45-59.

Park, B. M. (2013, Apr. 11). The average annual salary of K-League 
players is 144.61 million won. The Hankyoreh. Retrieved from http://www.hani.co.kr

Pieroth, B., Schlink, B., Kingreen, T., \& Poscher, R. (2015). Pieroth/schlink ua, grundrechte. staatsrecht ii. mit ebook. CF Müller GmbH.

Pyo, M. H. (2009). Das apothekenurteil des bundesverfassungs gerichts und interpretation der berufsfreiheit in Koreanische verfassung. Constitutional Law, 15(1), 423-453.

Seo J. H. (2016). A Study on the Application of the Monopoly Regulation Act over the Free Agent in KBO Rules. KHU Global Business Law Review, 9(2), 45-74.

Simmons, R. (1997). Implications of the Bosman ruling for football transfer markets. Economic Affairs, 17(3), 13-18.

Statistics Korea. (2017). 2017 Korean standard classification of occupations. Daejeon: Statistics Korea.

Sung, N. I. (2017). Constitution studies. Gyeonggi: Bobmunsa.

Tettinger, P. J. (2003). Selbstverwaltung in freiberuflichen Kammern. Jahrbuch des Kammer-und Berufsrechts, Baden-Baden: Nomos, 140, 152.
The Football Association. (2019). The FA handbook 2019/20. London: The Football Association.

Wieland, J. (2004). Kommentierung zu Art. 14 GG. Grundgesetz Kommentar, 1.

Yeun, K. Y. (2008). The problems in legal protection of sports player's contracts. The Journal of Comparative Law, 9(1), 85-112.

Yoo, G. R. (2017a). Discussion of the legal nature of professional sports player contract: Focusing on professional baseball player contract. The Journal of Sports and Entertainment Law, 20(1), 145-161.

Yoo, G. R. (2017b). Alegal review of professional baseball players' contracts: Focusing on the recent decision of the Korea fair trade commission. The Journal of Sports and Entertainment Law, 20(2), 93-113.

Yoo, G. R. (2017c). A brief review on the labor law Issues on the contract for professional baseball players. The Journal of Sports and Entertainment Law, 20(3), 91-108.

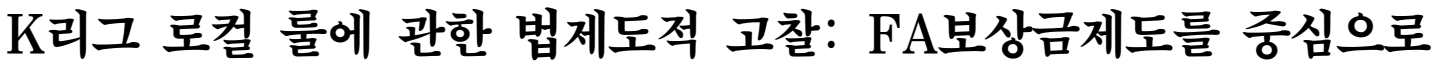

\author{
명왕성 ${ }^{1}$, 박광호 $^{2}$ \\ 1건국대학교, 연구교수 \\ ${ }^{2}$ 연세대학교, 시간강사
}

〔목적〕 본 연구는 $\mathrm{K}$ 리그의 선수계약과 관련된 로컬 룰, 즉 $\mathrm{FA}$ 보상금제도에 관한 법제도적 고찰을 제공하 는데 그 목적이 있다. 〔방법) (1) 프로축구선수의 근로자성에 대한 법적 개념을 검토하였으며, (2) 헌법에서 보장하는 기본권 관점에서 $\mathrm{FA}$ 보상금제도의 위헌적 요소를 체계적으로 검토하였다. 〔결과〕 첫째, FA보상금 제도는 계약이 만료된 선수에게 보상금을 요구하여 다른 구단으로의 이적을 제한한다는 점에서 「헌법」제 15 조 에서 규정한 직업 자유의 포괄적 개념 중 '직장선택의 자유'를 침해한다고 할 수 있다. 둘째, 직업(직장)선택의 자유가 「헌법」제 2 장 제 10 조에서 보장하는 행복추구권과 밀접한 관련이 있다는 헌법재판소 판례와 국가인권

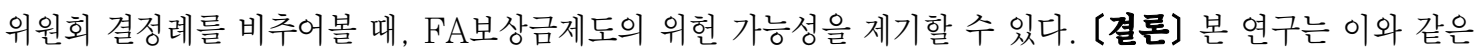
법리적 해석을 근거로 $\mathrm{FA}$ 보상금제도에 관한 전면 개정 또는 폐지에 대한 필요성을 제고하고, 후속 연구 및 정책 결정 과정에 기초적인 판단 자료를 제공했다는 점에서 학술적 및 실천적 의의가 있다.

주요어: FA보상금제도, $\mathrm{K}$ 리그, 프로축구, 선수계약, 직업선택의 자유, 행복추구권 